\title{
Specific Issues with Liquidation of the Mineral Deposit in Vazany by the Kromeriz
}

\author{
Martin Zidek ${ }^{1, *}$, and Michal Vokurka ${ }^{1}$ \\ ${ }^{1}$ VSB - Technical University of Ostrava, 70800, Ostrava-Poruba, F, 17. listopadu, 2175/15, Czech \\ Republic
}

\begin{abstract}
This paper investigates the problematic liquidation of now unused deposit of brick clay in south - eastern part of Czech Republic approximately $1.5 \mathrm{~km}$ to $\mathrm{SW}$ from the city centre of Kromeriz. Initially the condition of the deposit is described from the time of closure to the present day, including a detailed discussion of the problem. Main part of this paper is devoted to the design concept of reclamation of the unused deposit. The purpose and aim of this conception is to design a proposal of technical and biotechnical measures to create conditions for full-fledged reintegration of this segment of land, affected by mining, into it's surrounding area. The conception summarises the whole scale of necessary tasks needed to achieve remediation and reclamation of the area.
\end{abstract}

\section{Introduction}

There is an obligation in Czech Republic to liquidate the mines after the mining is terminated stipulated by Act No. 44/1989 Coll. about protection and utilization of mineral resources (Mining Act) [1]. Mining organization is according to $\S 32$ of this Act obligated to provide a Plan for the opening, preparation and extraction of mineral deposits which also includes the Project of remediation and reclamation. During the liquidation of extracted and unused mining area several complications may occur. These should be resolved by the mining organization, which was carrying out the mining, (Fig. 1).

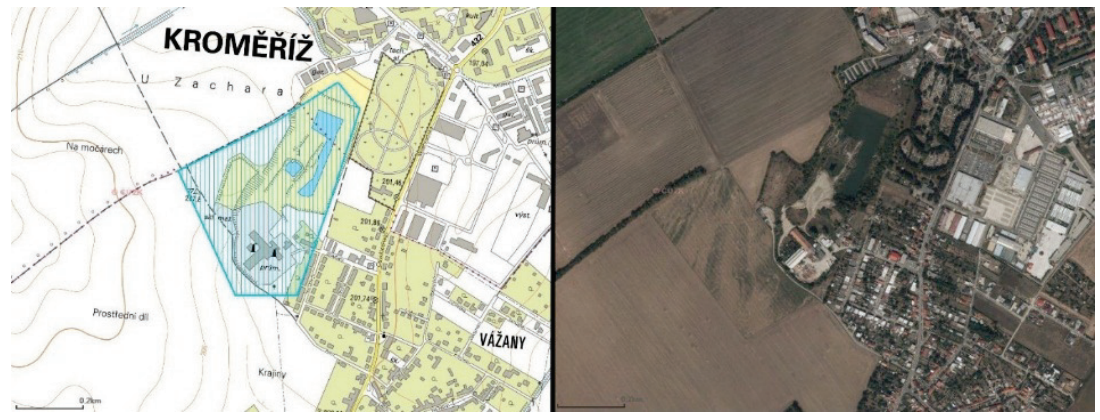

Fig. 1. Mining area of clay pit in Vazany (left) and satellite view (right).

\footnotetext{
*Corresponding author: martin.zidek87@gmail.com
} 
The attenuation and economic reasons caused that the brickyard in Vazany was closed in the 90's and the liquidation of the deposit of brick clay wasn't executed by the original mining organization. The whole area was returned to it is original owner during the property restitutions in the 90 's but in a devastated condition. During the limited operation, municipal waste was imported into the mining area. The original owner was unable to ensure to liquidate the deposit, so it was passed the right and duties associated with liquidation of the deposit to a private company. This company has several problems now ahead. The main problem is the mine drainage which can influence the stability and tightness of the landfill. Another problem is the problem of finances for the legislatively required liquidations of the deposit, problems with nearby built up areas and the technical part of liquidation, reclamation of mining area and it's further utilization.

\section{History of the Brickyard in Vazany}

The history of brickyard in Vazany started in 1897, when a group of entrepreneurs met in Kromeriz to discuss development of brickyard. Steam brickyard in Vazany began it is operation in 1900 under the name "KAMPF and co. steam brickyard Vazany". At first the brickyard was making full bricks, later the assortment was widened. The raw material was extracted by hand. The brickyard had a capacity of 2-5 million bricks per year. In 1941 the production was closed and renewed in 1946. In 1948 the company was nationalized as per the Act No. 114/1948 Coll. [2] about nationalization of some other industrial companies, which completed the decree of president Edvard Benes No. 100/1945 Coll. [3] which implemented nationalization of mines and some industrial companies.

The seasonal production at that time reached close to 5 million bricks a year. The brickyard has shut down in the 90's, (Fig. 2). During the restitutions the whole abandoned and decaying area was returned to it is original owner. This owner had the brickyard and clay pit up until 2019, when the right of disposal was passed on to Biotrend Morava LLC. This company is at present according to the effective legislation required to ensure the closure of the unused mining area, which is preceded by liquidation of all main mines, including reclamation of the affected area.

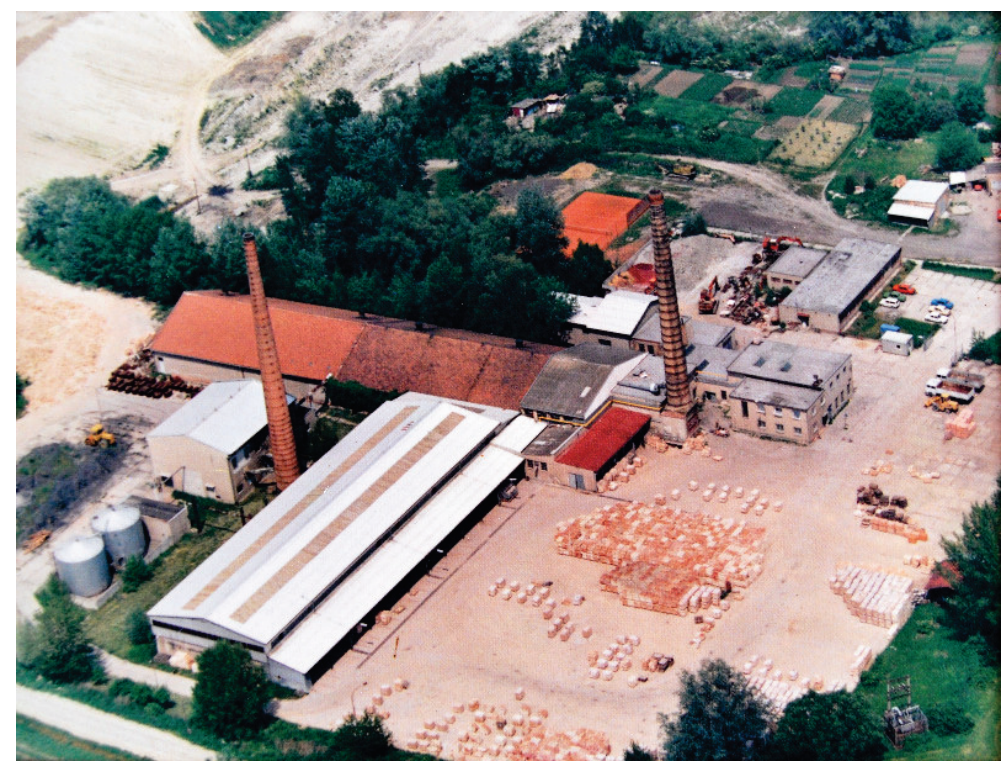

Fig. 2. Brickyard in Vazany in 1994. 


\section{Surface Mineral Deposit Vazany - Geographical and Other Context}

The area of interest is situated in South Moravian region, district Kromeriz, cadastral area Vazany and Kromeriz. The mine itself is found in a flat terrain between a village Vazany, whose built up area is also the SE border of the mining area, and city Kromeriz to the north of the mine. In the east it neighbours with the city Kromeriz's cemetery and in the SW and NW with agricultural lands. Elevation of the area of interest ranges from 199-207 m above sea level. From the hydrological point of view, the area belongs to the drainage of the river Morava. There is not any surface watercourse though nearby to the deposit, which would influence the hydrogeological characteristics of the deposit by infiltration.

The whole area designated for reclamation occupies about 7 ha, 2 ha of that are water bodies, (Fig. 3). Water surface is on the bottom of the clay pit and is in contact with the frontal slop of the reclaimed landfill owned by the city Kromeriz. A total of $95304 \mathrm{~m}^{3}$ of mine drainage was accumulated in the mining area in February 2018.

The mining operations in the mining area of the former brickyard in Vazany ceased in 1995. By the decision of the Ministry of Industry and Trade from 19.3.1999 to write-off of Vazany 's mineral resources were removed from the evidence.

The area of the deposit is nowadays divided into several parts. There is the excavated area, in it's western projection there is an already reclaimed landfill Vazany - brickyard. In the northern edge there is a landfill named Vazany - Zachar, which is still in use. A part of the excavated area is an upper lake situated in between the plant area and the landfill Vazany - brickyard. Lower lake is situated in the south-eastern part. Next there is the brickyard area with its manipulation sites and an area untouched by the mining operation in the area of the deposit.

At present is deposit still registered as a main mine workings with a determined mining area and was not removed from the evidence. In order to be removed, it is necessary to carry out liquidation and reclamation of the main mine workings. Afterwards the District Mining Authority which is based in Brno can make the decision about the removal the mining area from the evidence. Mine drainage and it's volume is a big problem in this regard.

Because of the contact of mine drainage with the frontal slope of the reclamation landfill and because of the technical aspects of the reclamation, it will be necessary to pump the mine drainage into the surface water during the reclamation.

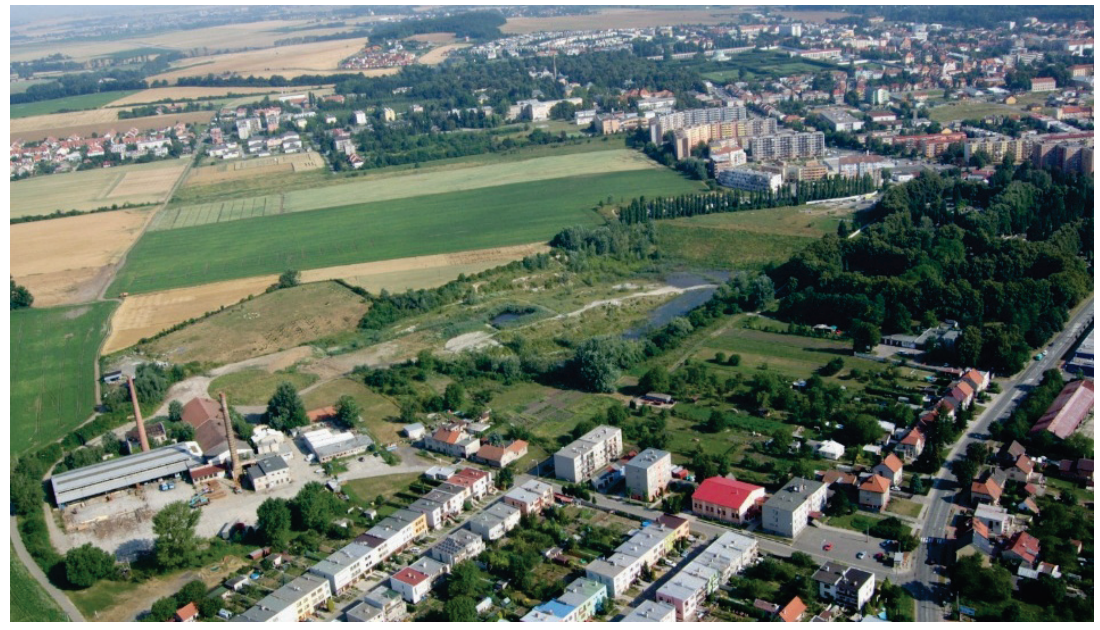

Fig. 3. Clay pit, former brickyard and housing estate. 


\section{Health Risk and Potentional for the City Development}

The brickyard Vazany is situated in a proximity to a housing estate Zachar and the city's cemetery. The excavated area of the deposit of an area of 9 ha was in the 70's and 80's intensively used to stocking solid municipal and other waste. Both massive bodies of landfills were reclaimed. Complicated proprietary rights, closeness to a residential area and bad connection to road infrastructure together with enormous financial demands lead to uncertainty about the realization of the whole project of reclamation.

At present the former clay pit is left to it's spontaneous evolution and because of the impermeable bedrock the bottom is slowly being flooded. Beside the risks of rising mine drainage levels there is also a problem of illegal waste disposal by citizens. Higher places are illegally filled with excavation dirt, and inert wastes such as construction wastes. In the case that the mine drainage is contaminated, the remediation will be problematic and extremely financially demanding due to the amount of water.

Due to safe movement of people and animals in the nearby areas it is necessary to start looking for a solution. Housing developments are starting to appear near the mining area. In case of the liquidation and reclamation being finished, this area will be having a great potential as a natural park, playground, etc.

\section{Mining Drainage of Mining Deposit Vazany}

On the bottom of the clay pit is a water body, which is in contact with the frontal slope of the reclaimed landfill owned by the city Kromeriz. The landfill covers an area of $1500 \mathrm{~m}^{2}$, depth of the waste is $12 \mathrm{~m}$. The whole volume of the waste is $180000 \mathrm{~m}^{3}$. The bedrock consists of clay with beds of weathered sandstones and sandy clay.

The slopes and bottom of the landfill in the deposit area is isolated by airtight and waterproof barrier made from polyethylene foil. The western slope is isolated by several layers of clay. Water drainage's monitoring is carried out from the drillings holes and collecting sump. The sump has two chambers and is used to measure the parameters of the drainage system, which drains the water under the landfill. In the other chamber infusion water is collected and then compared with the sewerage's limits. The infusions are not proved to have exceeding amounts of harmful substances which could have been pumped into the city's sewerage.

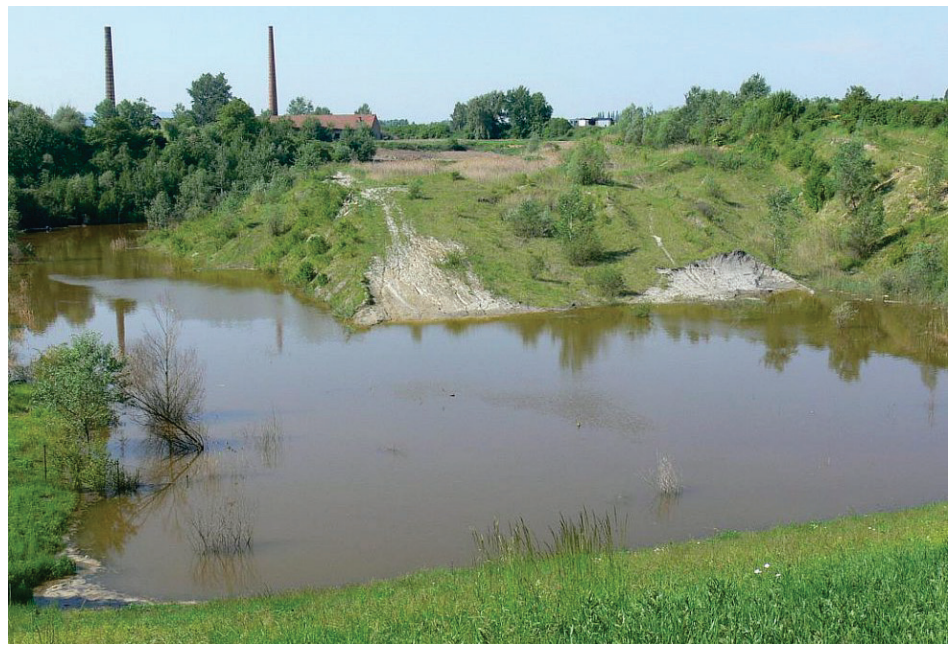

Fig. 4. Lake of mine drainage. 
Neither breaking of the dam or the seal system of the landfill isolation, or death of animals or harm to the ecosystem in the mining area were proved in 2007. After 2007 was the water part of the sump dry and water was being pumped. The landfill was drained, and the creation of biogas ceased. After 2009 the water level began to rise and in the mining area the dry two chamber sump and the western slope of landfill were flooded.

A total of $95304 \mathrm{~m}^{3}$ of mine drainage were accumulated in the mining area in 2018, see Fig. 4. The area has characteristics of no drainage basin, so accumulation is to be expected. The project of remediation and reclamation had to solve further security of the landfill regarding the rising water levels in the mining area and the amount of seepage mine drainage into the body of the landfill.

\section{Project of Remediation and Reclamation and Future Use}

The project of remediation and reclamation was prepared as a part of the Plan of opening, preparing and extraction of the main mine workings in Vazany in 1970, which assumed the final base of mining at the spot height of $191 \mathrm{~m}$ above sea level and the using of excavated space as a water reservoir. The project of remediation and reclamation of clay pit in Vazany from 1973 was engaged the reclamation for agricultural purposes with previous filling of the excavated space.

Supplement to the Plan of opening, preparing and extraction from 1978 expanded the mining area to $188 \mathrm{~m}$ above sea level and changed the method of utilization of the excavated area to a controlled landfill of solid municipal waste. In the next phase was to be reclaimed for agricultural purposes. For the technical parts of reclamation filling up with technological material such as excavation dirt or construction waste is assumed. The area covered by this project is limited by the municipal landfill Vazany - Zachar to the north and the border of the area of brickyard to the south.

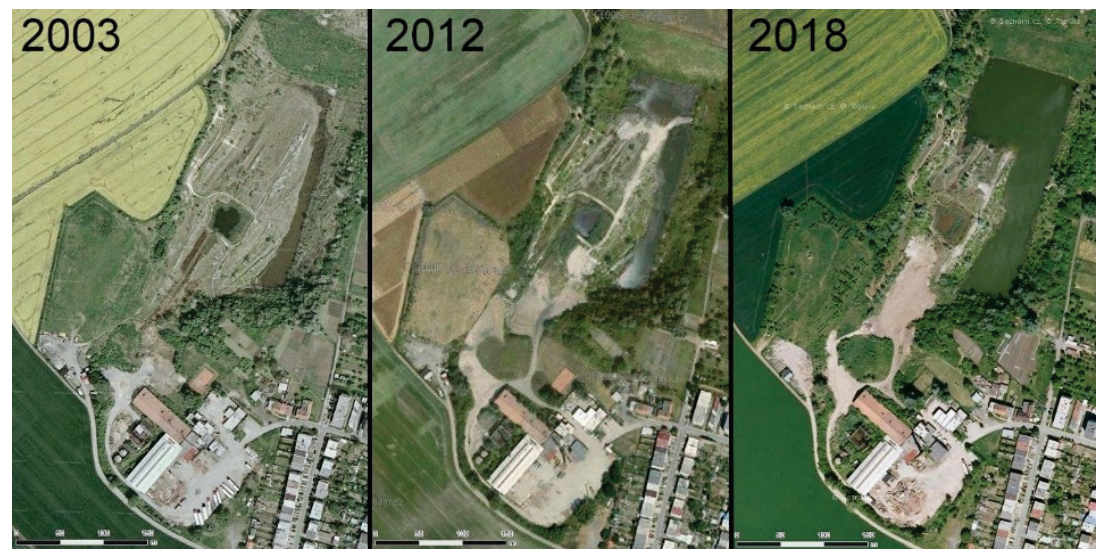

Fig. 5. Development of clay pit from the ceasing of mining to the current time.

The author's proposal introduces a concept of reclamation of the area of interest for further using such as green area with playgrounds and sportsgrounds, sport and cultural facilities. A small water body with shore become a small part of the area.

For that purpose, filling of the excavated space in the area with technological materials up to $1 \mathrm{~m}$ under the surface was suggested. In the area next to landfill Vazany - Zachar the filling will be done up to 4 meters below the predicted edge of the terminal slope. The connection to the area of landfill Vazany - brickyard, which was already reclaimed in the past - will be executed accordingly. 
Subsequent technical reclamation will be created an area with reclaimed layer of $1 \mathrm{~m}$ $(0,75 \mathrm{~m}$ of second soil horizon and $0,25 \mathrm{~m}$ of topsoil). Created area will follow the surrounding terrain and copy the original morphology. In the north-western part a small drop will be created at the slope of landfill Vazany - Zachar and similar drop will be created at the western edge at the slope of Vazany - brickyard. General inclination of the reclaimed area will be slightly tilted towards the east. The final utilization of the reclaimed areas will be covered by constituent execution projects subsequently to finishing filling up the excavated area.

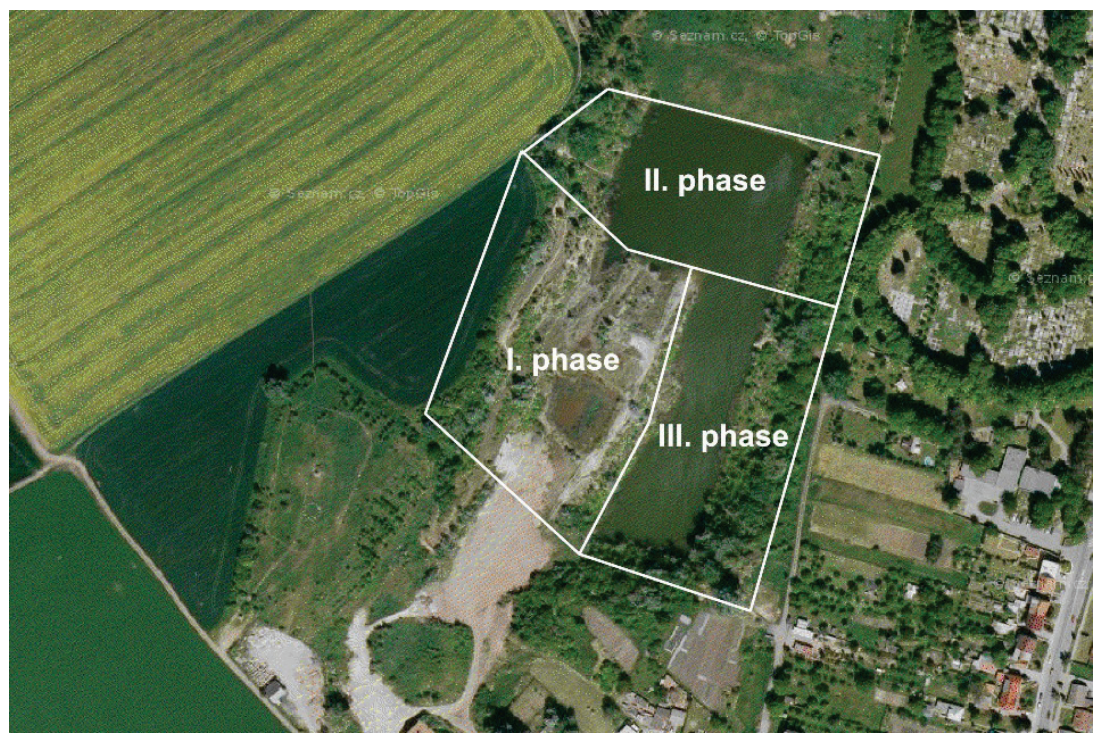

Fig. 6. Scheme of reclamation phases.

Reclamation is designed to be done in three phases, (Fig. 6), in succession to filling up with technological materials at the liquidation. The first phase is to do reclamation of the southern part above the area of the brickyard, the second phase is to reclaim the northern parts next to the landfill Vazany - Zachar and the third phase is to finish the middle part in between the previous ones, (Fig. 6).

During the technical reclamation it will be necessary to adjust the terrain and relief conditions of the reclaimed areas according to future use. After filling of the area with technological materials the phase of technical reclamation will level the surface. A layer of fertilization abled soils will be transported onto the levelled surface - that is second soil horizon of depth $0.75 \mathrm{~m}$ which will be covered by $0.25 \mathrm{~m}$ of topsoil.

During the third phase a hollow will be created in the current reservoir lake to create a lake of the area of $1500 \mathrm{~m}^{2}$. The depth of the hollow will be influenced by the ground water levels in the excavated area after it is stabilized so that the depth of the lake is at least $0.75 \mathrm{~m}$. The area of the lake is designed to be about $1000 \mathrm{~m}^{2}$.

The original project of remediation and reclamation assumed a creation of one large water reservoir in the excavated area. The material from performed uncovering was therefore used for other reclamation. Because of the change of the conception, it will be necessary to obtain needed amounts of topsoil and second horizon soils from different sources. During the process of filling up with technological materials the monitoring station of mine drainage will be moved from the surface level of the reservoir.

Biological reclamation will consist of greening the area by grass, planting trees and bushes. The area prepared this way will then be ready for further utilization.

Reclamation of the area affected by mining will be carried out subsequently to 
liquidation of the excavated area which is currently being realized and so it is necessary to count in the changing inflation during the following years. The fond for remediation and reclamation was not created during the times of mining and production, which contradicts the current legislative. Fond will be created using the funds gained from liquidation of the clay pit, which means from the fees from stocking municipal waste and filling up with technological materials appointed for liquidation.

\section{Conclusion}

The excavated area of the deposit of brick clays in Vazany presents a big problem nowadays. Liquidation will be financially and technically demanding process due to nonexisting financial fond from the past and a great amount of accumulated mine drainage. Mine drainage will have to be monitored all the time. The mine drainage needs to be removed before the liquidation and reclamation of the deposit in order to provide safety during the procedures.

From all the designed alternatives, the one the author is presenting seems to be the most appropriate one, because it is necessary to ensure total stability of the area including the two landfills located in the mining area. Therefore, it will be necessary to ensure isolation against free water leaking into the reclaimed area and at the same time leave free area on the surface for park adjustments including water components and possible recreational use in agreement with current trends in environmental protection.

This research was supported by the VSB - Technical University of Ostrava under Project SP2020/9 "Research of secondary mineralization and it's influence on flooding of uranium mine".

\section{References}

1. Act No. 44/1988 Coll., about protection and utilization of mineral resources (Mining Act) as amended

2. Act No. 114/1948 Coll., about nationalization of some other industrial companies

3. Act No. 100/1945 Coll., Decree of the President of the Republic about nationalization of mines and certain industrial enterprises

4. Bech, J., Bini, C., \& Pashkevich, A. M. (2017) Assessment, Restoration and Reclamation of Mining Influenced Soils. Academic Press. ISBN: 9780128095881

5. Coppin, N. J. \& Bradshaw, D. A. (1982) Quarry Reclamation: Establishment of Vegetation in Quarries and Open Pit Non-metal Mines. London: Mining Journal Books

6. Green, E. J. (1992) A User Guide to Pit \& Quarry Reclamation in Alberta. Alberta: Reclamation Research Technical Advisory Committee

7. Kim, M. S., Park, M. J., Yang, J. H., Lee, S. H. (2019) Human Health Risk Assessment for Toxic Trace Elements in the Yaro Mine and Reclamation Options. International Journal of Environmental Research and Public Health, 2019, 16 (24), art. no. 5077, doi: 10.3390/ijerph16245077

8. Laska, S. M. \& Ireland, W. A. (2019) A Conceptual Planning Framework to Improve Integration of Reclamation with Site Remediation. Ecological Restoration, 2019, 37 (4), pp. 263-272, doi: 10.3368/er.37.4.263

9. Notice of intent according to $\S 6$ of Act No. 100/2001 Coll. (as amended by Act No. 93/2004 Coll. and by Act No. 163/2006 Coll.), on Environmental Impact Assessment in the scope of Annex 3 fot the purposes of the screening procedure Liquidation I. Phase of Brickyard Vazany in the mineral deposit Vazany 
10. Plan of Reclamation and Remediation of Territory Affected by Mining in Mineral Deposit Vazany. Olomouc: Bansky inzenyring, s.r.o., 1999

11. Stys, S. (1981) Reclamation of Areas Affected by Mining and Quarrying. Praha: SNTL.

12. Vrablikova, et al. (2009) Methodology of Territorial Revitalization for Economic, Social and Environmental Development in the Affected Regions. Usti nad Labem: Jan Evangelista Purkyne University. Project WD-44-07-1 - Dilci cil - DC003

13. Wong, M. H. (1999) Remediation and Management of Degraded Lands. London: CRC Press 